\title{
V
}

\section{HEGEMONIA DO AGRONEGÓCIO E ACELERAÇÃO DA CONTRARREFORMA AGRÁRIA: AS POLÍTICAS DO GOVERNO BOLSONARO PARA O CAMPO*}

\author{
Dayse Maria da Silva Caciano de Oliveira \\ Douglas Ribeiro Barboza \\ Paulo Roberto Raposo Alentejano
}

\section{Introdução}

Ao fazermos uma análise inicial do governo Bolsonaro, é possível afirmar que sua política para o campo é marcada pela aceleração da contrarreforma agrária, contribuindo para o fortalecimento da hegemonia do agronegócio no Brasil. Nitidamente delineadas desde os tempos de campanha e reafirmadas após a assunção à cadeira presidencial, suas políticas paralisaram totalmente a criação de assentamentos rurais, a demarcação de terras onde vivem povos indígenas e territórios de comunidades quilombolas, além de incitar a violência contra essas populações e os movimentos sociais do campo - em especial o Movimento dos Trabalhadores Rurais Sem Terra (MST) -, permitindo-nos avaliar que há nítidos elementos de fascistização nas ações desenvolvidas por esse governo. ${ }^{1}$

É importante destacar que a prioridade para o agronegócio como base para o desenvolvimento do campo brasileiro, estabelecida pelo atual governo Bolsonaro, na verdade, intensifica (através de continuidades com algumas diferenciações) tendências que vinham se delineando nos governos desde o final da década de 1990. Apoiando-se no aparato estatal e sob as rédeas do capital fi-

\footnotetext{
${ }^{*}$ DOI - 10.29388/978-65-86678-40-6-0-f.131-165

${ }^{1}$ A própria nomeação de Luiz Antônio Nabhan Garcia para a Secretaria de Assuntos Fundiários indica essa tendência - afinal, trata-se do presidente licenciado da União Democrática Ruralista (UDR), organização patronal mais truculenta existente no campo brasileiro, associada historicamente a práticas violentas de combate a ocupações de terra e assassinato de trabalhadores rurais.
} 
nanceiro, o agronegócio tem sido fundamental na definição do movimento e das estratégias das classes sociais no campo, confrontando-se permanentemente com a proposta de reforma agrária camponesa e popular construída pelos movimentos sociais. De acordo com Fernandes (2004), o agronegócio é um novo tipo (e mais amplo) de latifúndio, cujo poder de concentração e dominação não se restringe somente à terra, mas também à tecnologia de produção e às políticas de desenvolvimento; um eufemismo para escamotear a imagem latifundista do modelo predador, expropriatório e excludente de desenvolvimento econômico da agropecuária capitalista, que carrega consigo toda a herança do atraso político e econômico, do trabalho escravo, do coronelismo e da subserviência.

Neste sentido, para que seja possível compreender a hegemonia do agronegócio - e as consequências que seu modelo de desenvolvimento econômico abalizado na agroexportação traz para a atual conjuntura brasileira - é necessário recuperarmos, neste presente capítulo, algumas mediações históricas que particularizam a questão agrária e a luta pela reforma agrária no Brasil. Analisar a questão agrária brasileira, levando em consideração as inúmeras transformações sofridas pela agricultura, bem como, situar o tema na atualidade, sem deixar de lado todo o histórico da luta pela terra no Brasil e a grande dimensão territorial do país, torna o tema cada vez mais complexo e alvo de discussão nos meios acadêmicos e políticos.

A questão da estrutura fundiária sempre esteve presente no cenário político nacional, formando as bases de uma política de extrema concentração social da propriedade de terra que não apenas gerou o latifúndio como também demarcou as estruturas de monopolização do poder por reduzidas elites. Ligada umbilicalmente ao processo histórico de colonização do país, a estrutura de ocupação da terra baseada na existência de latifúndios atravessou os diversos ciclos econômicos sem grandes alterações. Conforme nos sinaliza Martins (1999), assim como a questão da escravidão estava enraizada na constituição do Estado monárquico no Brasil imperial, a questão agrária é nuclear no processo constitutivo do Estado republicano e oligárquico no país.

A transição da "democracia dos oligarcas" para a "democracia do grande capital" aprofundou os vínculos de dependência externa, ao mesmo tempo em que não efetivou uma desagregação radical da herança colonial na conformação da estrutura agrária brasileira (IAMAMOTO, 2006). A implementação da política de "modernização da agricultura" no período do pós-guerra, com profundas transformações na esfera produtiva a partir de tecnologias proveni- 
entes da indústria, agravou este cenário. Este processo de modernização conservadora impulsionado pelo regime militar instaurado após o golpe de abril de 1964 intensificou os conflitos no campo, a expropriação do trabalhador camponês, ${ }^{2}$ e a própria inserção do Estado através de políticas que potencializaram a espoliação e a concentração fundiária.

Com a crise capitalista aberta nos anos 1970, formata-se um novo ciclo de acumulação caracterizado pela mundialização e a financeirização, cujo desenvolvimento atingiu a agricultura. A partir dos anos 1980, abre-se um cenário em que o papel da agricultura nucleou a gestão das várias conjunturas macroeconômicas do período, e a territorialização do capital promoveu a instalação de grandes complexos agroindustriais no campo, via monocultura, para exportação, potencializando a expropriação e a expulsão dos trabalhadores do campo para as cidades. A expansão do capital mundializado e financeirizado para o terreno da agricultura ganha um novo dinamismo a partir dos anos 1990/2000, impulsionado pela estratégia externa (e política agrícola interna) de priorização do agronegócio, a qual se tornou parte estruturante dos governos que assumiram a presidência desde então, e que se intensificou com a chegada ao poder de Jair Messias Bolsonaro, em 2018, cujas ações vêm contribuindo para o avanço dessa hegemonia através da intensificação da contrarreforma agrária.

São estas questões que serão desenvolvidas no capítulo aqui apresentado, no intuito de reforçar como a atual hegemonia do agronegócio potencializa problemas historicamente presentes no meio rural e que a luta contra este modelo de desenvolvimento capitalista na agricultura eleva a patamares mais am-

2 Compreendemos que o conceito de camponês é atual para a análise da compreensão da realidade agrária brasileira, porque nos permite conhecer a complexidade dos sujeitos históricos que institui, diversamente dos conceitos de pequena produção e agricultura familiar. Para a compreensão desse conceito, partimos principalmente das reflexões de Marques (2008) e Fernandes (2008), a partir dos quais entendemos que o campesinato é formado por uma diversidade de formas sociais baseadas nas relações de trabalho familiar e formas distintas de acesso à terra como o posseiro, o parceiro, o foreiro, o arrendatário, o pequeno proprietário, etc. Nesse sentido, entendemos que a centralidade do papel da família na organização da produção e na constituição de seu modo de vida, juntamente com o trabalho na terra constituem os elementos comuns a todas essas formas sociais. Enfim, partimos do apontamento de Marques (2008), a qual diz que, apesar do camponês ser um migrante expropriado, ele não rompe totalmente seus vínculos com a terra. Para esta autora, a maioria dos camponeses expropriados mantém alguma relação com o campo, seja ela mais próxima ou mais distante - relação direta de trabalho, vínculo familiares, relação de origem, etc. O que explica, em parte, a permanência entre eles de um conjunto de símbolos e valores que remetem a uma ordem moral ou lógica tradicional e a possibilidade de acesso à terra se apresentar como uma alternativa para pobres do campo e da cidade que buscam assegurar a sua sobrevivência mantendo a dignidade de trabalhador. 
plos e complexos os desafios a serem enfrentados pelos movimentos sociais na luta pela terra e pela reforma agrária no interior da sociedade brasileira.

\section{Particularidades históricas da questão agrária na forma- ção social brasileira}

Ao analisar a essência de nossa formação social, Prado Jr. esclarece que, quando o país foi dividido pelos portugueses em grandes extensões de terra, centralizando a produção para o abastecimento de mercados externos, a sociedade e a economia brasileiras se organizaram e funcionaram para produzir e exportar para a Europa alguns gêneros tropicais ou minerais de grande importância; isto é, tudo que nela existia foi subsidiário e destinado unicamente a amparar e tornar possível a realização do essencial objetivo exterior, contribuindo para a ocorrência da concentração fundiária e para uma forma de utilização da terra baseada na grande exploração agromercantil (PRADO JR., 2000, p. 117). O desenvolvimento das principais atividades econômicas ao longo do período colonial apresentava duas características fundamentais: uma diversidade regional significativa e uma política de ocupação de territórios que se interligava diretamente com a atividade mais lucrativa no momento (Idem, 2008). ${ }^{3}$

Nos marcos de um emergente mundo colonial, a manutenção da estratificação estamental, que servia de base social à existência e ao fortalecimento do Estado patrimonial no mundo colonial brasileiro, erigia-se sob a condição histórica de concessão de sesmarias, ${ }^{4}$ que demarcavam as estruturas de poder que não podiam nem deviam ser destruídas, conformando uma política de concentração de terra que não apenas gerou o latifúndio, como também:

3 Presenciou-se, por exemplo, o auge da economia açucareira durante o século XVII, destacadamente na Bahia e Pernambuco, devido ao clima favorável e à possibilidade de escoamento da produção devido à proximidade dos portos. No século XVIII, a descoberta das jazidas auríferas e diamantíferas em Minas Gerais direcionou para esta região o foco produtivo, o que impulsionou também o desenvolvimento das cidades em seu entorno, como o Rio de Janeiro (que se torna a capital) e São Paulo. Com o esgotamento das minas, a cena produtiva volta a ter em destaque a agricultura - especialmente com o açúcar, o tabaco e o algodão - e também a pecuária e seus derivados (como o leite, o queijo e o couro), a qual se desenvolveu particularmente nas regiões de Minas Gerais, Rio Grande do Sul e Mato Grosso.

4"Havia, sem dúvida, uma injustiça estrutural no regime sesmarial: só podia ser sesmeiro o homem livre e, até meados do século XVIII, puro de sangue e puro de fé. Aos índios aculturados e aos mestiços era, no geral, vedada a concessão da sesmaria, porque classificados na categoria de administrados, isto é, tutelados por um senhor branco e livre" (MARTINS, 2002, p. 164). 
[...] excluiu, ab initio, a massa da população livre, pertencente ou não à ordem estamental, da posse da terra e, por aí, do controle do poder e do direito de ter vínculos diretos com o Estado. Em si mesma, a terra não era uma riqueza e iria demorar algum tempo para que ela assumisse esse significado (mesmo como conexão do capital mercantil). Mas erigia-se na base material da transferência e da perpetuação de uma arraigada estrutura de privilégios e da própria dominação patrimonialista (FERNANDES, 1981, p. 69).

Compreendendo que a forma pela qual se operou a emancipação do Brasil foi o caráter de "arranjo político" (PRADO JR., 2012, p. 51), podemos afirmar que a particularidade do desenvolvimento desta transição contribuiu para a caracterização de todo o processo como uma "revolução encapuçada" (FERNANDES, 1976), sob a qual a Independência pressupunha tanto um elemento revolucionário quanto um elemento conservador. Seu elemento revolucionário emerge no fato desta representar um marco histórico definitivo da extinção do estatuto colonial e um ponto de referência para formação da sociedade nacional. Seu processo restaurador é solidificado pelo fato de que a profundidade da ruptura com o passado foi confinada pelo predomínio de influências his tórico-sociais:

A grande lavoura e a mineração, nas condições em que podiam ser exploradas produtivamente, impunham a perpetuação das estruturas do mundo colonial - da escravidão, à extrema concentração de renda e ao monopólio do poder por reduzidas elites, com a marginalização permanente da enorme massa de homens livres que não conseguia classificar-se na sociedade civil e a erosão invisível da soberania nacional nas relações econômicas, diplomáticas ou políticas com as grandes potências (FERNANDES, 1976, p. 33). ${ }^{5}$

O período que se abre a partir dos anos 1850 assinala o encaminhamento de várias modificações que buscavam mudar a fisionomia do país, tentando direcioná-lo para o que então se considerava modernidade: a redução e a extinção do tráfico de escravos, com a consequente liberação de capitais e experiência empresarial para investimentos produtivos em outros setores; a promul-

\footnotetext{
${ }^{5}$ A concentração do poder nas mãos de uma minoria explica “[...] a sobrevivência das estruturas tradicionais de produção e das formas de controle político caracterizadas pela manipulação do poder local pelos grandes proprietários e a marginalização e apatia da maioria da população" (COSTA, 2010, p. 60).
} 
gação da Lei de Terras $^{6}$ que instituiu a propriedade privada da terra e sua mercantilização; a centralização da Guarda Nacional; e a aprovação do primeiro Código Comercial. Durante todo o período imperial, a maioria das reformas propostas pelos liberais havia sido exclusivamente política (com exceção da Abolição), portanto não modificavam as estruturas econômicas, políticas e sociais mais profundas. O resultado desse processo de desenvolvimento foi a sobrevivência de estruturas de mando que implicaram na marginalização de amplos setores da população que, na prática, garantiam e reiteravam “[...] o monopólio do aparelho estatal por parte dos donos de escravos, senhores de engenho, fazendeiros de café, estancieiros, proprietários de terras, negociantes, interesses estrangeiros" (IANNI, 1985, p. 11).

Durante a República Velha, o Brasil manteve-se como um país predominantemente agrícola até os anos 1930. De acordo com o último censo realizado neste período (1920), apenas $16,6 \%$ da população vivia em cidades de 20 mil habitantes ou mais, e $69,7 \%$ se ocupava em atividades agrícolas, enquanto 13,8\% se dedicavam à indústria e 16,5\% aos serviços (FAUSTO, 2012). Na sociedade rural, dominavam os grandes proprietários, que antes de 1888 eram também, na grande maioria, proprietários de escravos. Com a sustentação do poder radicada na propriedade da terra e na riqueza, os "coronéis" passavam a exercer funções públicas através de um sistema de reciprocidades e de troca de favores em relação aos seus dependentes, mediante recursos do Estado. O coronelismo se conforma, assim, como um fenômeno indicador da "[...] rarefação do poder público frente ao poder privado ou a privatização de funções e de recursos públicos em funções de interesses privados” (IAMAMOTO, 2007, p. 139).

\footnotetext{
${ }^{6}$ Segundo Medeiros (2003, p. 10), "Quando, em meados do século XIX, começaram a surgir dificuldades para a continuidade do uso de mão de obra escrava, uma vez que o tráfico negreiro passou a ser publicamente condenado e duramente perseguido no plano internacional, o debate sobre novas formas de trabalho para as grandes lavouras também passou a ser uma discussão sobre o uso da terra e as condições de sua apropriação. Nesse momento, embora já aparecessem no Parlamento vozes favoráveis a uma divisão de terras, prevaleceu o poder dos grandes proprietários. O resultado da polêmica em torno da apropriação e do uso da terra foi a Lei de Terras, aprovada em 1850. Por meio dela garantiram-se mecanismos que possibilitaram a manutenção da concentração fundiária e da disponibilidade de mão de obra. A Constituição republicana de 1891 e o Código Civil de 1917 os mantiveram”. Promulgada por um Parlamento constituído de grandes fazendeiros e senhores de escravos, a Lei de Terras "[...] transferiu ao particular domínio e posse, criando uma espécie de direito absoluto que é a principal causa do latifundismo brasileiro e das dificuldades para dar à terra, plenamente, uma função social" (MARTINS, 1999, p. 122). As consequências dessa legislação se mostram bem evidentes anos depois, por volta de 1920, nos marcos da República Velha, onde “[...] 4,5\% daqueles que podiam comprar, possuíam praticamente a metade das propriedades rurais do país" (COGGIOLA, 2007, p. 3).
} 
O liberalismo político dominante na organização federalista da Primeira República instituiu a autonomia dos Estados, o que interessava à oligarquia cafeeira e ao particularismo de seus negócios. No artigo 64 da Constituição Federal de 1891 (BRASIL, 2020a), garantia-se a transferência das terras públicas federais ao patrimônio dos estados da federação, dando-lhes a prerrogativa de legislar sobre elas. Esta medida contribuiu para a formação de amplos domínios fundiários, prevalecendo a ordem latifundiária das elites agrárias imperiais. ${ }^{7}$

A política dos governadores desenvolvida ao longo da Primeira República assentou uma estrutura política que representava o retorno dos proprietários de terra ao poder e " [...] permitia às classes dominantes dos Estados mais poderosos somar as disputas das oligarquias estaduais e as desigualdades regionais, de modo a preservar e fortalecer o poder do grupo que dominava o aparelho estatal" (IANNI, 1985, p. 15). Eram várias as formas de exploração do trabalho no interior das relações de produção em vigor, tornando a Primeira República cenário privilegiado do que Candido (1989) denominou de "esquema decididamente espoliador" enraizado em nossa sociedade. No campo, vínculos empregatícios contaminados dos vícios do passado não muito distante configuravam situações que beiravam à escravidão, onde empregados se viam presos a patrões por dívidas muitas vezes impossíveis de saldar. O excesso de população rural que facilitava a exploração da mão de obra fácil e barata; os obstáculos ao acesso à terra própria; o predomínio dos grandes proprietários e "coronéis", tudo isso tornava desumana e lastimosa a semi-existência dos que nela vegetavam na extrema necessidade. As condições de uma estrutura agrária de características coloniais - com a grande propriedade e a monocultura que persistiu como ocupação da terra e como regime de exploração - impediu a melhoria das condições do homem do campo mesmo com os abalos da abolição. Esta situação não foi alterada pela República. Pelo contrário, a grande concentração que se desenvolve até a crise de 1929-1930 não somente contribuiu para a expansão da área das culturas agrícolas, como também gera a miséria e as fomes que dramatizam o cotidiano nordestino na época das secas.

\footnotetext{
${ }^{7}$ De acordo com Rodrigues (1982, p. 83), a atribuição das terras devolutas aos estados trouxe como consequência “[...] não só o fracionamento da massa territorial, como permitiu as concessões despidas de interesse público, feitas em atos isolados de favor que favoreciam os latifundiários ou permitiam a partilha de quase todo um estado, como o Amazonas, dividido em oito zonas, entregues a companhias estrangeiras para a exploração de suas riquezas minerais". Outra medida adotada pelo governo republicano foi a regularização dos arrendatários de terras públicas - grandes proprietários que ocupavam as terras públicas sem qualquer mecanismo legal, tornando-os como donos legais de grandes áreas arrendadas.
} 
O aumento dos conflitos foi a consequência inexorável deste processo (BARBOZA, 2014). O acirramento da "questão social" desencadeia um conjunto de lutas sociais no campo pela garantia dos direitos dos trabalhadores camponeses. ${ }^{8}$ Presencia-se a explosão de centenas de greves por salários e melhores condições de trabalho, como as ocorridas nas fazendas de café de São Paulo. O desmoronamento econômico, a destruição social, a subjugação política, o deserto dos valores morais e culturais motivam a reação que se manifesta de formas diferenciadas no sertão. Contra o monopólio da terra, contra a exploração do trabalhador rural pelo latifundiário, contra a seca, contra as fomes periódicas e até mesmo contra a repressão policial inundada de abusos e sanguinarismo, o cangaço representava uma forma de luta, uma resposta contra a organização social nordestina (RODRIGUES, 1982). Nestes marcos,

O mundo rural revela o peso da violência do Estado, como marca do capitalismo dependente, avançando sobre o direito dos trabalhadores incorporando e superando formas de exploração pré-capitalistas e suas ideologias de conservação que responsabilizam o trabalhador rural explorado pela sua condição social e econômica (BARBOZA et al, 2019, p. 62).

Após a "revolução de 1930", que decretou o fim da República Velha, conformava-se uma faceta da modernização da sociedade brasileira; uma transição que inaugurava, ainda sob hegemonia da oligarquia, "uma recomposição das estruturas do poder, pela qual se configurariam, historicamente, o poder burguês e a dominação burguesa", recomposição esta que marcara a ultrapassagem da "era senhorial" (ou antigo regime) da "era burguesa" (ou sociedade de classes) (FERNANDES, 1976, p. 203). A "Revolução Constitucionalista" de

\footnotetext{
${ }^{8}$ É inocultável o fato de que as inúmeras lutas e resistências concernentes à questão do poder cristalizado na forma do monopólio da terra se desenvolvem desde a invasão portuguesa. São alguns exemplos deste período: a constituição de quilombos por negros e índios escravizados, tendo sido Palmares uma referência histórica por volta de 1629, o confronto indígena liderado por Sepé Tiaraju (1753-1756), a Conjuração Baiana (1798), a Insurreição dos Malês (1835), a Balaiada (1838), a Cabanagem (1835), a Sabinada (1837), a Revolução Praieira (1848-1850), a Guerra de Canudos (1896-1897) e a Guerra do Contestado (1912-1916). Nas décadas seguintes ao período referenciado no parágrafo, podemos destacar: a Revolta do Caldeirão (1935), Movimento Pau de Colher (1935), a Guerrilha de Porecatu (1944-1951), diversas organizações de posseiros por volta de 1957 a 1961, a Revolta de Trombas e Formoso (1955-1964), a União dos Lavradores e Trabalhadores Agrícolas do Brasil - Ultab (1954), as Ligas Camponesas (19551964), o Movimento de Agricultores Sem Terra - Master (1960) e o avanço da sindicalização rural na década de 1960 .
} 
1932 e a promulgação da Carta Constitucional em 1934 (BRASIL, 2020b) revelariam que a força política das oligarquias rurais não havia sido inteiramente destituída, o que forçava a necessidade de recomposição do pacto de poder entre essas oligarquias e a burguesia industrial e comercial em ascensão. Tal processo culminou, por um lado, na preservação das estruturas de propriedade herdadas de quatro séculos passados, sem sinalização de alterações no tocante à Reforma Agrária. Por outro, implicou na manutenção das condições políticas dos grandes proprietários de terra para exercerem o poder nas áreas rurais, conservando, com base no monopólio das instituições do Estado, um forte controle sobre a população rural, garantindo assim a manutenção da sua força de representação política (mesmo que num plano secundário).

Absorvendo os excedentes populacionais da agricultura de exportação, e caracterizada pela substituição de importações e pela concentração na produção de bens de consumo duráveis, a industrialização realizou-se sem efetivar uma ruptura tanto com a dependência econômica dos países centrais quanto com a oligarquia rural (da qual são originárias as novas elites dominantes).

Formata-se, assim, um período longo onde vigora a estreita relação entre o capital e a propriedade da terra; um pacto onde a grande lavoura se constitui como base da acumulação de capital e da diversificação econômica. Sob esses moldes, diferentemente dos modelos econômicos clássicos em que a propriedade do capital e a propriedade da terra foram separadas - e, paralelamente, separou-se também a classe dos capitalistas da dos proprietários de terras aqui, ambos se fundiram; e, não raro, na grande propriedade, o proprietário se fez não apenas um latifundiário (no sentido tradicional da palavra), mas um empresário (MARTINS, 2002, p. 170). A velha oligarquia agrária se recompõe e refaz alianças para permanecer no bloco do poder, modernizando-se economicamente e influenciando decisivamente as bases conservadoras da dominação burguesa no Brasil.

\section{As amarras do processo de modernização capitalista da agricultura no Brasil}

Durante os anos 1950, com o modelo de industrialização dependente que resultava na necessária importação de máquinas da Europa e dos EUA, era a geração de divisas provenientes da continuidade das exportações agrícolas que tornava possível o pagamento desse montante de maquinário derivado da im- 
portação. De acordo com Stedile (2005, p. 31), desse processo surge um setor industrial vinculado à produção de insumos para a agricultura (como ferramentas, máquinas, adubos químicos, venenos etc.); e outro setor ligado à implantação da indústria de beneficiamento de produtos agrícolas (a denominada agroindústria), modelo este que fez emergir também uma burguesia agrária, de grandes proprietários, que buscava modernizar a sua exploração agrícola e destinála ao mercado interno, num processo de modernização capitalista da grande propriedade rural. $\mathrm{Na}$ estrutura da propriedade da terra, construía-se, assim, uma lógica contraditória e complementar:

Por um lado, havia a multiplicação de pequenas propriedades, pela compra e venda e reprodução das unidades familiares. E, por outro lado, em vastas regiōes, a grande propriedade capitalista avançava e concentrava mais terra, mais recursos. E, no geral, havia uma tendência histórica, natural da lógica de reprodução capitalista, de que a propriedade da terra, que já nasceu em bases latifundiárias, continuava na média se concentrando ainda mais (STEDILE, 2005, p. 32-33)

Se a importação de meios de produção considerados mais modernos marcou os primeiros passos, ainda na década de 1950, do processo de modernização capitalista da agricultura no Brasil, será a partir da década de 1960, especialmente com o iniciar dos governos militares derivados do golpe de 1964, que a agricultura será inserida mais fortemente na realidade da produção capitalista, através da implementação de planos de desenvolvimento econômico que objetivavam adequar a produção dos bens primários ao capital financeiro (DELGADO, 2012, p. 13-15). Quando o país passa a ser dirigido pela autocracia civilmilitar burguesa, de meados dos anos 1960 aos anos 1980, é implementada uma nova etapa da modernização conservadora. O Estado dirigiu essa mudança de rumo criando as bases para a acumulação de capital, através da regulação da relação entre capital e trabalho, fundamentalmente pelas leis trabalhistas; da transferência de recursos para a empresa industrial e da promoção de mudança qualitativa no âmbito da produção agrícola, que continuou sendo importante para a dinâmica capitalista internacional, mas passou a ter igualmente um papel primordial para alimentar as massas urbanas, isto é, na produção para o mercado interno.

No que diz respeito à política voltada para o desenvolvimento agrícola, é implementada uma série de mecanismos para beneficiamento da produção agrícola em larga escala - através, sobretudo, de créditos para insumos químicos 
e maquinaria para os grandes proprietários, implementando a chamada Revolução Verde. ${ }^{9}$ Esta deu um impulso ao processo de modernização da agricultura, dando início à mecanização e ao envenenamento da produção agrícola, como forma de aumentar a produtividade e, ao fim e ao cabo, a lucratividade. Ademais, com a internacionalização das terras da Amazônia, o crescimento e beneficiamento dos latifúndios, e uma contrarreforma agrária associada à colonização das áreas de fronteiras, intensificaram-se os conflitos agrários, tendo destaque o papel da militância sindical. Não por casualidade, a ditadura empresarialmilitar perseguiu, prendeu, torturou e desapareceu com lideranças camponesas e, a partir de 1972, empurrou para os sindicatos rurais a responsabilidade de prestar assistência médica e dentária e também o encaminhamento para aposentadorias e pensões de forma a burocratizar e despolitizar suas lutas.

Esse modelo econômico de modernização da agricultura no país, que manteve a concentração de terras e potencializou a monocultura de exportação, teve como principal fator de fortalecimento o interesse do capital internacional que estava investido na indústria nacional, o qual necessitava tanto expandir a produção de bens e insumos para a agricultura, quanto aumentar a produção e exportação a partir da matéria-prima brasileira (PALMEIRA, 1989). Neste cenário, a produção agrícola ou agroindustrial passou a ser invadida por grandes grupos econômicos, os quais passaram a imobilizar capitais em terras, no intuito de se beneficiarem não somente com a valorização das mesmas, mas também com a possibilidade de captação de recursos públicos para a realização de aplicações financeiras que fossem mais lucrativas naquele momento. De acordo com as análises de Müller (1989, p. 34):

Com a integração indústria e agricultura no período de 1960-80, deparamo-nos com empresas e grupos econômicos que influenciam poderosamente a dinâmica das atividades agrárias, com profundas repercussões em suas estruturas. Mas na própria agricultura surgem empresas e grupos econômicos, que com suas congêneres industriais, fazem parte do poder econômico com interesses nas atividades agrárias.

\footnotetext{
9 No pós-II Guerra Mundial, em oposição à Revolução Vermelha (que propunha uma transformação social radical, alterando a estrutura do sistema produtivo que gera relações sociais com profundas desigualdades, como expressam a miséria e a fome), criou-se a Revolução Verde como uma alternativa técnica para aumentar a produtividade e solucionar o problema do abastecimento de alimentos no mundo (CARNEIRO, 2015). Ironicamente, chegamos ao século XXI com 1 bilhão de famintos, como a própria ONU, através da Organização das Nações Unidas para a Alimentação e a Agricultura (FAO), reconhece.
} 
Delgado (2005) nos sinaliza que a década de 1980 se conformou como um momento de transição e contradição para a Questão Agrária brasileira, com a retomada de fôlego, após o término do regime militar, das forças sociais que durante duas décadas haviam sido subjugadas pelo domínio autoritário da modernização da agricultura. ${ }^{10}$ Além disso, se entre 1965-1981 a agricultura brasileira completou um ciclo de modernização técnica e crescimento sem efetivar uma alteração substantiva na estrutura agrária, a partir dos anos 1980 se abrirá um cenário em que o papel da agricultura se conformará como crucial para a gestão das várias conjunturas macro-econômicas do período. A moratória mexicana de 1982 desencadeou uma crise de liquidez internacional, o que contribuiu para o longo período de relativa estagnação da economia brasileira, em grande medida estabelecida pelas sucessivas operações de "ajustamento" macroeconômico à crise do endividamento externo, realizadas de forma a tentar adequar a dinâmica econômica interna aos limites que as novas restrições externas lhe impunham.

Assim, este processo de "ajuste constrangido" à ordem econômica globalizada (a que o país se submete ao longo das décadas de 1980/90 e que adentra os anos 2000), teve como características básicas as restrições de ordem externa e interna, expressas por alto endividamento público e dependência externa, ${ }^{11}$ além da influência da economia internacional na economia política da questão agrária.

A maneira como o establishment econômico promoverá a gestão da crise da dependência externa a partir da reversão do ciclo econômico de crescimento em 1982 requer uma participação expressiva do setor agrícola e das cadeias agroindustriais conexas na geração de saldos de comércio exterior. Estes passam a ser essenciais para suprir as necessidades de financiamento do déficit em conta corrente do balanço de pagamentos.

A forma como a política econômica externa incorporará o setor agrícola na "solução" do endividamento externo reforça a estratégia de concen-

\footnotetext{
10“'Com o ambiente de abertura política ocorre uma articulação ampla dos movimentos sociais e entidades de assessoria agrária: nasce o Movimento dos Trabalhadores Rurais Sem Terra (MST), reorganiza-se a Confederação Nacional dos Trabalhadores na Agricultura (Contag), a Comissão Pastoral da Terra da Conferência Nacional dos Bispos do Brasil (CNBB), criada em 1979, é fortalecida pela Igreja e surgem várias organizações não governamentais (ONGs) em apoio ao 'Fórum Nacional pela Reforma Agrária"' (DELGADO, 2005, p. 61).

${ }^{11}$ Cabe ressaltar que, no essencial, esses "ajustes macroeconômicos" não foram capazes de equacionar esses endividamentos. "Ao contrário, prolongam essa fase de estagnação da economia brasileira por mais de duas décadas" (DELGADO, 2005, p. 62).
} 
tração e especulação fundiária no mercado de terras. O maior sinal disto é a liberalidade com que propicia a apropriação da renda fundiária pelos grandes proprietários (DELGADO, 2005, p. 62)

Durante as décadas de 1990/2000, o capital mundializado expande cada vez mais os seus "tentáculos" para o âmbito da agricultura, a qual passa a ser requisitada a atender às exigências desse "ajustamento constrangido" e aos endividamentos interno e externo. Conforma-se, assim, um novo momento de impulso à estratégia externa de priorização do agronegócio e dinamização do setor agroexportador, associada à nova política econômica mundial de financeirização do capital, onde a mercantilização das terras e as exportações de produtos primários são potencialmente valorizados. A política anteriormente utilizada no cenário de modernização conservadora dos anos 1960/80 - de investimentos em complexos industriais associados à grande propriedade privada da terra para responder à balança comercial externa - é retomada neste novo período de limiar do século XX e início do século XXI, com priorização da agricultura capitalista do agronegócio na agenda macroeconômica externa e na política agrícola interna, como forma de geração de saldos de comércio exterior para suprir o déficit da conta corrente.

A estratégia de desenvolvimento baseada na implementação de "cinturões de desenvolvimento" a partir dos "eixos de integração" com alternativas de integração regional, tende a perpetuar a fragmentação espacial do desenvolvimento em função do fluxo internacional de mercadorias, expressa na Iniciativa para a Integração da Infraestrutura Regional Sul-Americana (IIRSA). ${ }^{12}$ Dessa forma, materializa mais uma etapa das reformas estruturais de feição neoliberal, perpetuando assim a fragmentação espacial do desenvolvimento e o acirramento dos conflitos no campo diante da reprimarização das exportações, tendo em vista que as áreas agricultáveis estão sendo disputadas pelas corporações internacionais. O país é colocado "[...] em liquidação para o capital que busca reprodução no portentoso negócio das exportações de commodities" (LEHER, 2009, p. 72, grifo do autor).

As respostas dos governos federais de orientação neoliberal ao quadro mais amplo da questão agrária nacional e do desenvolvimento agrícola foram,

\footnotetext{
12 Trata-se de um programa que envolve os doze países da América do Sul, que visa promover a integração dessa região com a modernização da infraestrutura, transporte, energia e telecomunicação. Financiado pelo BID, CAF e FONPLATA e também governos nacionais, tem sido alvo de diversas críticas, sobretudo por movimentos ambientalistas, devido às causas dos diversos impactos ambientais dos empreendimentos adotados.
} 
em síntese: de promoção de políticas de acesso à terra via mercados; de créditos voltados para a integração vertical dos produtores considerados eficientes; de fomento aos pacotes tecnológicos que associam o uso de sementes transgênicas com o uso de defensivos que causam danos agudos e crônicos aos trabalhadores rurais, danos ambientais através do envenenamento do solo, água, ar e dos próprios alimentos que chegam à mesa dos consumidores; de reprimarização das exportações por meio da prevalência do latifúndio, associado ao capital internacional para a produção de commodities, e da exploração predatória de minérios; da combinação de alta tecnologia empregada no agronegócio com trabalho análogo ao escravo; de estrangeirização de terras $;^{13}$ de crescimento de ocupação de territórios indígenas e de populações tradicionais, em nome do desenvolvimento; de projetos de desenvolvimento territoriais sustentáveis combinados com políticas sociais compensatórias que não alteram a estrutura da produção agrícola; dentre outras expressões. De forma mais intensa e escancarada, o Estado brasileiro combina a criminalização dos movimentos sociais campesinos com políticas públicas que despolitizam a questão agrária e arrefecem as lutas sociais.

\section{A hegemonia do agronegócio no campo brasileiro}

A partir destas reflexões, é importante ressaltar que a prioridade para o agronegócio como base para o desenvolvimento do campo brasileiro, estabelecida pelo atual governo Bolsonaro, aprofunda tendências que vinham se delineando desde o segundo mandato do governo Fernando Henrique Cardoso (FHC), atravessaram os governos petistas de Luís Inácio da Silva (Lula) e Dilma Roussef e desaguaram no governo Michel Temer. O agronegócio foi definido por Delgado (2006, p. 1) como uma “[...] associação do grande capital agroindustrial com a grande propriedade fundiária, sob patrocínio fiscal, financeiro e patrimonial do Estado". Consideramos importante acrescentar a essa definição a sustentação político-ideológica da grande mídia empresarial - não à toa, os grandes grupos empresariais da mídia integram a Associação Brasileira do Agronegócio (ABAG).

A prioridade política conferida ao agronegócio vem do final da década de 1990: quando pressionado pela crise cambial de 1998/1999, o governo FHC

\footnotetext{
13 Segundo Stédile (2013, p. 29): “[...] estima-se que as empresas estrangeiras devem controlar mais de 30 milhões de ha de terras no Brasil".
} 
estimulou as exportações como forma de obter saldos na balança comercial para pagar as dívidas do país. Entre os setores estimulados estava o agronegócio, livre do pagamento de impostos sobre a exportação de produtos primários, desde a Lei Complementar 87/1996, conhecida como Lei Kandir (BRASIL, 1996).

Configura-se, a partir de então, um movimento para elevar o agronegócio à condição de um dos pilares da economia brasileira, ao mesmo tempo em que a reforma agrária era apresentada como anacrônica e os movimentos sociais do campo como violentos e atrasados. Com o aumento da demanda mundial das chamadas commodities, na década de 2000, impulsionado pelo crescimento da economia chinesa, as exportações brasileiras de produtos agropecuários se expandiram fortemente em quantidade e valor, e o agronegócio foi se fortalecendo cada vez mais. $\mathrm{O}$ valor médio anual das exportações passou de 50 bilhões de dólares no período 1995/99 para cerca de 200 bilhões no final da década de 2000, com a participação dos produtos básicos passando de $25 \%$ para $45 \%$ da pauta de exportações em 2010 e, somados aos semimanufaturados, este número passa para 54,3\%, configurando a reprimarização do comércio exterior (DELGADO, 2012, p. 95).

Esta estratégia política de ancorar a economia na exportação de commodities não foi exclusiva do Brasil, disseminando-se por toda a América Latina, configurando o que Svampa (2013) denominou de "consenso das commodities", quer dizer, uma espécie de consenso político e ideológico de que a única via legítima ou possível para o desenvolvimento é através da exploração intensiva e em grande escala de recursos naturais para a produção de produtos primários.

Para este crescimento do agronegócio contribuiu, decisivamente, a adoção de um conjunto de políticas: trabalhistas, que promoveram a flexibilização das relações de trabalho; ambientais, cujos marcos regulatórios foram revisados; de infraestrutura, sobretudo escoamento da produção; de ordenamento territorial e regularização fundiária; e de financiamento (HEREDIA; LEITE; PALMEIRA, 2010).

Alavancado por este conjunto de políticas públicas, o agronegócio também foi favorecido, contraditoriamente, pela crise econômica-alimentar-energética-ambiental de 2007/2008, uma vez que esta desencadeou um forte crescimento dos investimentos estrangeiros no setor, seja para investir na produção de alimentos e agrocombustíveis, cujos preços se elevaram, seja porque em períodos de crise a terra é vista como uma reserva de valor. Embora este cenário tenha sofrido certa inflexão a partir de 2010, com a queda do preço das commoditi- 
es agrícolas, em especial a soja, houve rápida recuperação dos preços, e a consolidação do Brasil como principal fornecedor da China permitiu a continuidade do crescimento do agronegócio ao longo da década de 2000, embora com oscilações.

O resultado desse modelo de desenvolvimento tem sido a intensificação da concentração de terras, revelando que o Brasil não foi capaz de transformar a estrutura fundiária. Pelo contrário, a manutenção da concentração em nossas terras foi e é funcional para o domínio capitalista. Segundo o Incra (2020a), há 5.766 .542 milhões de imóveis rurais no Brasil registrados no órgão que, juntos, somam 521.837.119 milhões de hectares (ha) de terras. O último censo agropecuário do IBGE, de 2017, comprova a concentração de terras no Brasil, apontando que $77 \%$ das terras dos estabelecimentos agrícolas estão nas mãos do agronegócio (IBGE, 2019).

Todavia, o crescimento da grande propriedade não se traduz em ampliação do emprego rural nem tampouco melhores condições de salários como nos revela os dados apurados no mesmo documento. Das 5 milhões de propriedades agrícolas no país, pouco mais de 51 mil detêm 47,6\% terras usadas para produção agropecuária. Por outro lado, pequenos proprietários, donos de terras com até 10 ha, ocupam somente 2,3\% do total. A pesquisa aponta ainda outra tendência: a diminuição dos estabelecimentos ocupados pela agricultura familiar e, consequentemente, o encolhimento dos postos de trabalho. A redução foi 9,5 pontos percentuais em relação a 2006. O segmento também foi o único a perder mão de obra: enquanto houve um incremento de 702 mil postos de trabalho em outros setores do agronegócio, a agricultura familiar perdeu um contingente de 2,2 milhões de trabalhadores (IBGE, 2019). ${ }^{14}$

Com isto, segundo dados do IBGE (2020a), entre 1990 e 2018, a área plantada com lavouras temporárias no Brasil aumentou de 45,98 para 73,23 milhões de ha (isto é, cresceu 27,25 milhões de ha), aumento concentrado basicamente em três produtos voltados prioritariamente para exportação ou transformação indústria - as chamadas commodities - soja, cana e milho. A área plantada com estes três produtos passou de 27,2 milhões de ha em 1990 para 61,43 milhões de ha (um crescimento de 34,2 milhões de ha). Por outro lado, a produção de três alimentos básicos para a alimentação dos brasileiros, arroz, feijão e man-

\footnotetext{
14 Contudo, em termos de volume da produção e geração de renda, as pequenas unidades superaram as médias e grandes evidenciando que a reforma agrária não é uma pauta ultrapassada, mas uma necessidade concreta para o presente e futuro do país.
} 
dioca, diminuiu de 11,44 milhões de ha em 1990 para 6,04 milhões de ha (uma redução de 5,4 milhões de ha).

Outro dado revelador dos caminhos da produção agropecuária brasileira é o relativo à expansão da criação de bovinos no Brasil, atividade que se caracteriza pelo caráter extensivo, e cujo número de cabeças (213,5 milhões) já é maior que o número de brasileiros (210 milhões). Neste caso observamos que a criação de bovinos se expandiu em todas as regiões do país, mas com destaque para a Amazônia, onde a expressão foi mais significativa, passando de 17,8\% do rebanho brasileiro em 1990 para 40,6\% em 2018 (IBGE, 2020b).

A expansão do agronegócio não significou a melhoria das condições alimentares para a população brasileira, ao contrário, aumentou a insegurança alimentar no país. Entre 1990 e 2018, a população brasileira passou de 149 para 208,4 milhões de habitantes, um crescimento de 39,9\%. No mesmo período, a produção de arroz aumentou 58,3\% e a de feijão 30,5\%; ou seja, a de arroz su perou o crescimento populacional, mas a de feijão ficou abaixo deste. O caso da mandioca é ainda pior, pois a produção diminuiu $27,5 \%$. Assim, quando consideramos a disponibilidade de alimentos por habitante, observamos que esta se reduziu $1 \mathrm{~kg}$ no caso feijão e quase $80 \mathrm{~kg}$ no caso da mandioca. Já no caso do arroz houve um aumento de $6,6 \mathrm{~kg}$ por habitante (IBGE, 2020b).

Por outro lado, a produção de milho cresceu $285,5 \%$, a de cana-deaçúcar $184,3 \%$ e a de soja $492,5 \%$, o que confirma a prioridade da agricultura brasileira atual pelos produtos voltados para exportação ou a produção de matérias primas para a indústria em detrimento da produção de alimentos para a população, apontando para a inexorável ampliação de nossa insegurança alimentar, decorrente de um modelo produtivo que expande a produção de commodities em detrimento da produção de alimentos (IBGE, 2020b).

No rastro do crescimento econômico, o agronegócio foi também se fortalecendo politicamente. Não à toa, praticamente todos os ministros da Agricultura nas últimas duas décadas foram figuras de destaque do agronegócio, como Roberto Rodrigues (então presidente da $A B A G)$ no primeiro governo Lula, Kátia Abreu (à época presidente da Confederação Nacional da Agricultura) no governo Dilma, Blairo Maggi (um dos maiores produtores de soja e dono da maior empresa de processamento e comercialização de soja brasileira) no governo Temer, e Tereza Cristina (então líder da "Bancada Ruralista" na câmara, oficialmente denominada de Frente Parlamentar da Agropecuária - FPA) no governo Bolsonaro. 
Talvez a maior expressão política do fortalecimento do agronegócio seja o crescente poder desta "Bancada Ruralista", a qual vem atuando na defesa dos interesses do agronegócio no Congresso e se tornou a maior e mais influente bancada setorial do parlamento brasileiro. Na legislatura 2014-2018, a Bancada possuía 214 deputados e 24 senadores associados - respectivamente, $41,7 \%$ do total de deputados e $29,6 \%$ do total de senadores. A Bancada cresceu ainda mais na atual legislatura, iniciada em 2019, somando 225 deputados e 32 senadores - o que corresponde a 43,9\% da Câmara e 39,5\% do Senado.

O fortalecimento da "Bancada Ruralista" implica o aumento da capacidade do agronegócio de pressionar por políticas públicas que favoreçam o setor; mas vai muito além disso, pois trata-se de um segmento com nítidas e crescentes articulações com outras bancadas que se fortaleceram nos últimos anos, como a evangélica e a armamentista, conformando o que vem sendo denominado de "bancada BBB"15 - do boi, da bíblia e da bala -, ao que alguns acrescentam um outro B, o dos bancos, indicando a associação dos interesses da oligarquia financeira com os setores mais retrógrados da sociedade brasileira.

\section{A aceleração da contrarreforma agrária}

Lastreado pelo apoio do agronegócio e sustentado politicamente pelas bancadas dos "Bs", o governo Bolsonaro, eleito em 2018, suspendeu qualquer destinação de terras para criação de assentamentos rurais, terras indígenas e territórios quilombolas; criou mecanismos para franquear as terras dos assentamentos e indígenas para a expansão do agronegócio e outros interesses do capital - como a mineração e a construção de hidrelétricas - e intensificou a legalização da grilagem de terras, em especial na Amazônia. Além disso, extinguiu programas como o Pronera ${ }^{16}$

15 A expressão faz referência a um programa televisivo e foi utilizada pela primeira vez pela deputada Erika Kokay, do PT. Ver Rocha (2015), disponível em: $<$ https://epoca.globo.com/colunas-e-blogs/felipe-patury/noticia/2015/02/kokay-aumentabancada-bbb-biblia-boi-e-bala.html>, acesso em: 07 set. 2020.

16 Por meio do Pronera, jovens e adultos de assentamentos têm acesso a cursos de educação básica (alfabetização, ensinos fundamental e médio), técnicos profissionalizantes de nível médio, cursos superiores e de pós-graduação (especialização e mestrado). O programa também capacita educadores para atuar nos assentamentos e coordenadores locais - multiplicadores e organizadores de atividades educativas comunitárias. As ações do programa, que nasceu da articulação da sociedade civil, têm como base a diversidade cultural e socio-territorial, os processos de interação e transformação do campo, a gestão democrática e o avanço científico e tecnológico. 
e Terra do Sol. ${ }^{17}$

Já dizia Marx que, para desvendar as relações sociais, precisamos ir muito além das aparências. Nada mais falacioso do que o discurso dos ideólogos do agronegócio de que a terra já não é mais fundamental para a agricultura contemporânea, pois esta é intensiva em capital e tecnologia. Terra é não só fundamental para o agronegócio, como hoje também é para uma série de outras estratégias do capital, dentre elas a especulação movida por grandes empresas transnacionais, bem como fundos financeiros os mais diversos, que cada vez mais investem em terras como ativos financeiros.

Assim, o agronegócio, ao mesmo tempo, atua para impedir a desapropriação das terras improdutivas situadas dentro de suas propriedades e avançar sobre as terras públicas e comunitárias no Brasil, que somam 39\% do território brasileiro e estão hoje fora do mercado de terras - pois trata-se de terra sob controle estatal (Unidades de Conservação, Terras Indígenas e Assentamentos Rurais) ou tituladas coletivamente (Territórios Quilombolas).

O processo de incorporação de novas áreas é condição fundamental para a dinâmica do agronegócio, ampliando o domínio territorial e abrindo novas fronteiras através da acumulação por espoliação (HARVEY, 2004), processo violento de apropriação e expropriação dos recursos naturais, terras e territórios, que imprime nos territórios padrões de conflito expressos em sistemáticos despejos, cessão irregular de terras, cerceamento de acessos públicos, cercamento de terras de uso coletivo, impedimento de acesso à água, captação em escala industrial dos recursos hídricos, desmatamentos, entre outros conflitos.

Nesta perspectiva, áreas de preservação ambiental, terras indígenas, quilombolas, de assentamentos rurais e de uso comum são obstáculos a serem removidos, visando ampliar a oferta de terras no mercado que vive momento de intenso aquecimento.

O abandono da reforma agrária e do reconhecimento de terras tradicionalmente ocupadas por indígenas e quilombolas já dura mais de uma década.

\footnotetext{
17 Programa de fomento à agroindustrialização e à comercialização por meio da elaboração de planos de negócios, pesquisa de mercado, consultorias, capacitação em viabilidade econômica, além de gestão e implantação/recuperação/ampliação de agroindústrias. Atividades não agrícolas - como turismo rural, artesanato e agroecologia - também são apoiadas. A ação foi criada em 2004 e faz parte do Plano Nacional de Reforma Agrária (PNRA) e do Plano Plurianual (PPA), que define os programas prioritários do Governo Federal. Durante esse período, foram disponibilizados $\mathrm{R} \$ 44$ milhões em recursos, que propiciaram a implantação de 102 projetos e beneficiaram 147 mil famílias em todo o Brasil.
} 
Os dados sobre a criação (e reconhecimento) ${ }^{18}$ de assentamentos indicam que, no segundo governo Lula, já houve um recuo para patamares inferiores aos do governo FHC. No período que abrange os governos Sarney, Collor e Itamar (1985-1994), foram criados 868 assentamentos de um total de 9.415 criados entre 1985 e 2019 - o que corresponde a 9,2\% do total. Já nos dois governos FHC (1995-2002), foram criados 4.281 assentamentos, 45,5\% do total, principalmente no primeiro mandato, antes do giro primário-exportador. Nos governos Lula (2003-2010), foram criados 3.544 assentamentos, 37,6\% do total, mas com uma grande diferença entre o primeiro mandato, quando foram criados $2 / 3$ destes e o segundo mandato, com apenas 1/3. A partir de 2011, nos governos Dilma e Temer (2011-2018), a queda na criação de assentamentos é ainda mais brutal, com números anuais inferiores a todos os anos entre 1995 e 2010 e um total de assentamentos criados na década de 2010 de apenas 722, correspondendo a 7,7\% do total, menos que no período 1985-1994.

Portanto, a determinação de Bolsonaro de paralisar completamente a criação de assentamentos apenas radicalizou uma política que já vinha sendo delineada anteriormente, em consonância com os interesses do agronegócio.

Não foi muito diferente o cenário em relação a terras indígenas (TIs) e territórios quilombolas (TQs). No que diz respeito à demarcação de terras indígenas, o número cai vertiginosamente na década de 2010 até zerar no governo Bolsonaro, conforme anunciado pelo próprio presidente em agosto de 2019, em flagrante desrespeito à Constituição que, no seu artigo 231, prevê a demarcação das terras indígenas: "Enquanto eu for presidente não tem demarcação de terra indígena" (VERDÉLIO, 2019). ${ }^{19}$

O maior número de homologações de TIs ocorreu nos anos imediatamente posteriores à promulgação da Constituição de 1988, ao assassinato de Chico Mendes ${ }^{20}$ e às vésperas da Rio-92, Conferência das Nações Unidas sobre Meio Ambiente e Desenvolvimento, contexto em que havia grande pressão internacional pela adoção de medidas de preservação da Amazônia e dos direitos

$18 \mathrm{O}$ reconhecimento refere-se a assentamentos criados por governos estaduais e municipais que são integrados à base de dados do Incra e seus beneficiários considerados aptos a receber as políticas desenvolvidas pelo órgão de apoios ao desenvolvimento dos assentamentos.

19 Cf. <https://agenciabrasil.ebc.com.br/politica/noticia/2019-08/bolsonaro-diz-que-naofara-demarcacao-de-terras-indigenas $>$. Acesso em: 16 ago. 2020.

${ }^{20}$ Chico Mendes foi uma importante liderança dos seringueiros do Acre que se notabilizou pela defesa de uma reforma agrária adaptada à Amazônia e ao modo de vida dos seringueiros e outros povos da floresta. Sua defesa da preservação da floresta Amazônica lhe rendeu fama internacional, mas sua luta contra grileiros e latifundiários lhe rendeu inimigos que acabaram por assassiná-lo em dezembro de 1988. 
indígenas. Até 1992, foram homologadas 39,9\% do total de TIs criadas entre 1985 e 2019. O segundo período de maior criação de TIs foi o governo FHC, com 32,3\% do total. Nos governos Lula, foram criadas 19,4\% das TIs. Já na década de 2010, período que engloba os governos Dilma, Temer e Bolsonaro foram apenas $4,9 \%$ do total.

Assim, mais uma vez, o que observamos é que o governo Bolsonaro radicaliza uma tendência já delineada anteriormente de abandono da política de demarcação de TIs.

No caso dos territórios quilombolas o cenário também não é diferente. Tal como no caso dos indígenas, com demonstrações de racismo explícito, o presidente rejeita o cumprimento dos dispositivos constitucionais que asseguram o direito dos quilombolas aos territórios que tradicionalmente ocupam: "essas demarcações de terras quilombolas, têm 900 na minha frente para serem demarcadas, não pode ocorrer. Somos um só povo, uma só raça” (PARAGUASSU, 2020). ${ }^{21}$

A Comissão Pro-Índio que acompanha as políticas indígenas e quilombolas aponta a existência de 182 comunidades quilombolas, tituladas pelo Incra e por órgãos estaduais de terra. De acordo com este levantamento, até 2014 foram realizadas $84,6 \%$ de todas as titulações, e o período 2011-2014, que corresponde ao primeiro governo Dilma, foi o que teve maior quantidade de titulações. O que não quer dizer que tenha sido este governo o responsável pelas titulações pois, segundo o levantamento da Comissão Pro-Índio, órgãos federais foram responsáveis por apenas $23,2 \%$ das titulações ao longo de todo o período, ao passo que órgãos estaduais fizeram $76,8 \%$ das titulações - com destaque para o Instituto de Terras do Pará (Iterpa), que fez 30,3\% de todas as titulações realizadas no país, e para o Instituto de Terras do Maranhão (Iterma), que fez $29,2 \%$, ambos superando o Incra, que fez somente $20,5 \%$.

Desta forma, podemos concluir que também a política de reconhecimento de territórios quilombolas já vinha em desaceleração antes mesmo do governo Bolsonaro, portanto, como nos demais casos, o que Bolsonaro faz é radicalizar uma tendência já em curso.

O primeiro objetivo do agronegócio em relação à política fundiária é o de impedir que novas áreas sejam destinadas à reforma agrária, à criação de terras indígenas e territórios quilombolas. Este objetivo vinha sendo contemplado

21 Cf. <https://www.terra.com.br/noticias/brasil/bolsonaro-diz-que-nao-ira-demarcar-maispedidos-de-terras-quilombolas,c84b0e29893073548b2d922fc2c843b43hikpw6z.html>.

Acesso em: 16 ago. 2020. 
de forma crescente desde o final da década de 2000, ainda no segundo governo Lula, e foi acentuado ao longo da década de 2010, chegando ao estágio atual de atendimento pleno no governo Bolsonaro.

O segundo objetivo é abrir novas fronteiras para o agronegócio nas terras públicas brasileiras, recolocando no mercado as terras dos assentamentos e permitindo a exploração privada de terras indígenas, ainda que estas se mantenham públicas.

A titulação definitiva dos lotes dos assentamentos foi a forma encontrada pelo agronegócio para recolocar no mercado as terras desapropriadas para fins de reforma agrária ou colocar no mercado terras públicas que foram destinadas à criação de assentamentos rurais.

Embora conste da legislação brasileira sobre reforma agrária desde 1993, a prática de concessão de títulos definitivos pouco foi aplicada no Brasil desde então, prevalecendo a titulação provisória que impedia a recolocação da terra no mercado.

De acordo com Fernandes (2020, p. 7), em 2017 foram expedidos 26.563 Títulos de Domínio (TDs) e 97.030 Contratos de Concessão de Uso (CCUs), mais que nos dez anos anteriores, e em 2019 foram mais 852 TDs e 14.868 CCUs. Já o Relatório de Gestão do Incra de 2018, sem detalhar que tipo de título foi distribuído, aponta a emissão de 87.751 títulos em 2017 e 112.846 títulos em 2018. ${ }^{22}$

Assim, o que observamos é que as ações do governo Bolsonaro em relação à privatização das terras dos assentamentos representam uma continuidade do que foi realizado pelo governo Temer, distinguindo-se, neste sentido, expressivamente do que foi a política dos governos petistas (ALENTEJANO, 2018).

O segundo movimento fundamental de incorporação de novas terras à dinâmica expansiva do agronegócio é a abertura da exploração das terras indígenas. Este objetivo, há muito acalentado pelos ruralistas e objeto de inúmeros projetos legislativos, foi encampado pelo governo Bolsonaro neste ano de 2020, através do envio ao Congresso do Projeto de Lei 191/2020, que regulamenta a exploração econômica em terras indígenas por terceiros (BRASIL, 2020c). Entre as atividades liberadas estão o arrendamento de terras indígenas para a produção agropecuária, inclusive de produtos transgênicos, a mineração e o garimpo, a exploração de petróleo e a construção de usinas hidrelétricas. Segundo o

${ }^{22}$ INCRA (2020b). Disponível em: < http://antigo.incra.gov.br/pt/relatorios-gestao >. Acesso em: 13 set. 2020. 
projeto, os povos indígenas só poderiam vetar o garimpo, todas as outras atividades podem ser autorizadas, mesmo contra a vontade destes.

Calcula-se que haja 3,1 milhões de ha ilegalmente arrendados em TIs que seriam imediatamente legalizados, além da possibilidade de expansão para outros milhões de ha (GONZALES, 2019). ${ }^{23}$ No caso da mineração, só na Amazônia, há solicitação para pesquisa e lavra mineral sobre uma área de 30 milhões de ha localizados em TIs, em especial nas terras Yanomami, Raposa Serra do Sol (em Rondônia) e Alto Rio Negro (Amazonas) (PRIZIBISCZKI, 2020)..$^{24}$

Mas, o mais escandaloso dos processos em curso no campo brasileiro hoje é a escalada da grilagem de terras, do qual o mais recente episódio foi a edição da MP 910 pelo governo Bolsonaro no final de 2019. Mas Bolsonaro não foi o único a propor, nos últimos anos, ações favoráveis à grilagem de terras. Lula e Temer também o fizeram.

Desde o início da colonização portuguesa no que hoje é o Brasil, que instituiu o latifúndio e com ele as práticas de grilagem de terras, até o final do século XX, houve dois momentos de legalização da grilagem em larga escala no Brasil: a Lei de Terras de 1850 e o Decreto de 1931 de Vargas (OLIVEIRA, 2010, p. 38).

Já nas duas décadas do século XXI foram criadas nada menos que quatro legislações destinadas a regularizar a ocupação de terras públicas no Brasil, favorecendo os processos de grilagem de terras: as Leis 422/2008 e 458/2009 no governo Lula (BRASIL, 2008; 2009), a Lei 13.465/2017 no governo Temer (BRASIL, 2017) e a MP 910/2019 do governo Bolsonaro (BRASIL, 2019a). Essa profusão de novas legislações atende aos interesses do agronegócio que precisa de documentos legais de terra para acessar créditos e outros recursos públicos.

A MP 910/2019, proposta no final de 2019, caducou diante das dificuldades para realização de votações no Congresso no contexto da pandemia da Covid-19, mas foi transformada no Projeto de Lei 2.633/2020 e seguem as pressões do agronegócio pela sua aprovação. A MP propôs três alterações fundamentais na política de regularização fundiária em vigor, que já eram amplamente favoráveis à grilagem: (1) reafirma a ampliação da área máxima a ser re-

${ }^{23}$ Cf. <https://brasil.mongabay.com/2019/03/brasil-quer-legalizar-o-arrendamento-agricolade-terras-indigenas $>$. Acesso em: 16 ago. 2020.

24 Cf. <https://www.oeco.org.br/reportagens/mineracao-em-terras-indigenas-a-proposta-dogoverno-bolsonaro-em-10-perguntas-e-respostas >. Acesso em: 09 fev. 2020. 
gularizada, para 2.500 ha; (2) dispensa a fiscalização ou vistoria para a regularização; (3) amplia o prazo de ocupação.

$\mathrm{O}$ aspecto mais escandaloso da MP é a previsão da autodeclaração como base para a regularização fundiária. A MP amplia de 4 para 15 módulos fiscais o tamanho da área que pode ser regularizada sem que haja verificação local da situação, sem que seja conferido se há conflito envolvendo a área ou crimes contra a legislação ambiental ou trabalhista. Basta a apresentação de autodeclaração do pretenso proprietário. Vale dizer que o módulo fiscal no Brasil varia de 5 a 110 ha, o que significa dizer que áreas de até 1.650 ha poderão ser regularizadas sem qualquer fiscalização, a não ser que o "proprietário" declare que desmatou irregularmente, que submeteu algum trabalhador a trabalho escravo ou que assassinou alguém em conflito por aquela terra (BRASIL, 2019a).

O PL 2.633/2020, que substituiu a MP 910, pouco difere desta, sendo a única diferença expressiva a redução do tamanho da área passível de ser regularizada mediante autodeclaração de 15 para 6 módulos, com o intuito de reduzir as críticas de que estariam sendo beneficiados grandes grileiros (BRASIL, 2020d).

Como sabemos de longa data, grilagem, desmatamento e violência são processos absolutamente associados na dinâmica histórica de ocupação do território brasileiro, desde a colonização quando os povos originários foram dizimados e expulsos do litoral outrora habitado por estes em meio à Mata Atlântica, da qual também pouco restou. Esta histórica prática genocida e ecocida, infelizmente, se atualiza constantemente no campo brasileiro, agora sob o comando do grande capital, renovando a violência contra movimentos sociais, povos e comunidades tradicionais.

Não por casualidade, a luta pela terra contra esse modelo, que extrai de forma predatória os recursos naturais e superexplora a força de trabalho, é acompanhada pelo protagonismo dos movimentos sociais brasileiros. Ao contrário dos governos anteriores, que buscaram formas de dividir, cooptar ou controlar os movimentos sociais e povos indígenas e quilombolas, abrindo para isso canais de diálogo com estes - ainda que muitas vezes de forma seletiva, escolhendo os interlocutores e marginalizando movimentos tidos como mais combativos - o governo Bolsonaro estabeleceu uma política deliberada de enfrentamento com estes movimentos, qualificando-os, mais do que como adversários políticos, como inimigos. A resposta do Estado a esses sujeitos que lutam por reforma agrária, tendo como pauta a soberania alimentar e agroecologia, é a criminalização. Ainda na campanha referiu-se assim às ocupações de terras rea- 
lizadas pelo MST: "A propriedade privada é sagrada. Temos que tipificar como terroristas as ações desses marginais. Invadiu? É chumbo!" (AGÊNCIA ESTADO, 2018). ${ }^{25}$

Em consonância com esta posição, propôs a Lei 13.870/2019 (BRASIL, 2019b), aprovada pelo Congresso em setembro de 2019, que estabelece a posse estendida, isto é, a possibilidade de que proprietários rurais não apenas mantenham armas em casa, mas possam portá-las em todo o perímetro de suas propriedades. Os efeitos da nova lei em termos de aumento da violência no campo no período de boom do agronegócio ainda não são mensuráveis, uma vez que a referida lei entrou em vigor no último trimestre de 2019, mas os dados da Comissão Pastoral da Terra (CPT) acerca dos conflitos e da violência no campo mostram que 2019 foi ainda mais violento que anos anteriores, com o maior número de conflitos da década, com aumento de $23 \%$ em relação ao ano de 2018. Houve um aumento de $14 \%$ no número de assassinatos (passando de 28 para 32); 7\% nas tentativas de assassinato (de 28 para 30); e 22\% nas ameaças de morte, (que passaram de 165 para 201). O mesmo relatório também registrou o maior número de assassinatos de lideranças indígenas dos últimos 11 anos (de 9 indígenas assassinados em conflitos no campo no ano, 7 eram lideranças). Além disso, houve aumento dos conflitos por terra entre os conflitos no campo na última década. Entre 2007 e 2009, os conflitos por terra representavam $40 \%$ a $50 \%$ dos conflitos no campo, este patamar mudou para $50 \%$ a $65 \%$ entre 2010 e 2015 e pulou para mais de 70\% em 2016, mantendo-se neste patamar nos anos de 2017 e 2019, com leve oscilação para 65\% em 2018 (CPT, 2020).

Vale registrar ainda o crescimento dos conflitos por terra em termos absolutos, pois estes passaram dos 1.000 casos pela primeira vez em uma década, em 2016, o que se repete em 2019, quando atinge o pico de 1.254 conflitos, mais do que o dobro do que a média anual dos anos 2007 a 2010. Mais espantosa ainda é a disparada na área disputada nestes conflitos nos últimos anos. De um patamar inicial entre 13 e 14 milhões de ha entre 2009 e 2012, houve uma queda nos anos de 2013 e 2014 para cerca de 7 milhões de ha, mas a partir de então os números dispararam para cerca de 22 milhões de ha em 2015 e 2016, 38 milhões de ha em 2017 e 2018 e impressionantes 53 milhões de ha em 2019 (Ibidem).

25 Cf. <https://www.otempo.com.br/politica/invadiu-e-chumbo-afirma-bolsonaro-empalestra-no-rio-de-janeiro-1.1789465>. Acesso em: 22 maio 2020. 
Podemos inferir que os conflitos no campo não são casos isolados, mas um projeto de matança. A CPT, a comunidade acadêmica, representantes políticos e movimentos sociais relacionados à luta pela terra e meio ambiente têm importante papel na denúncia desses casos para que possamos mudar essa realidade e propor uma nova forma de desenvolvimento diferente da proposta mercadológica que visa lucros e não vidas. Estamos diante de uma verdadeira explosão da disputa por terra no campo brasileiro, evidenciando a falácia do discurso dos ideólogos do agronegócio de que a terra não importa para o setor. Importa e não hesitam em recorrer à violência para obtê-la, afinal, o capitalismo do século XXI faz da violência um método de renovação da dinâmica da acumulação, como nos lembra Bartra (2015, p. 128, tradução nossa):

[...] no terceiro milênio temos um capitalismo desgrenhado que recorre sistematicamente à economia violenta da "acumulação por despossessão", temos também uma ordem burguesa aprisionada e autoritária que, tanto a nível global como nacional, recorre sistematicamente à violência política primária permanente $[. ..] .{ }^{26}$

É a velha acumulação primitiva descrita por Marx se reformulando em pleno século XXI, combinando expropriação e violência, ou, no dizer de Harvey (2004), a acumulação por espoliação em andamento, acelerando a marcha da contrarreforma agrária.

\section{Considerações finais}

De uma maneira geral, pode-se afirmar que mudam os governos, mas sem mudanças estruturais na questão agrária a favor dos trabalhadores. Ou seja, a "armação" latifundiária brasileira vem mantendo, e agora intensificando, as mesmas ofensivas violentas e autoritárias, com um misto de elementos arcaicos e modernos.

O governo Bolsonaro, em seu primeiro ano de mandato, cumpriu regiamente o que foi anunciado durante a campanha no que se refere às políticas para o campo, priorizando o agronegócio, estimulando a grilagem de terras e a

\footnotetext{
26“"En el tercer milenio tenemos a un capitalismo desmecatado que recurre por sistema a la economía violenta de la "acumulación por desposesión", tenemos también a un orden burgués atrabancado y autoritario que tanto en el plano global como en el nacional, recurre sistemáticamente a la violencia política primaria permanente $[\ldots]$ ”.
} 
violência contra os movimentos sociais do campo, em especial o MST, os povos indígenas e quilombolas.

Entretanto, nem tudo nestas políticas representa ruptura com os governos anteriores. A prioridade para o agronegócio, por exemplo, remonta ao segundo governo FHC, atravessou incólume os governos petistas e desaguou no governo golpista de Temer. $\mathrm{O}$ abandono da reforma agrária, da demarcação de terras indígenas e quilombolas e a colocação em marcha da contrarreforma agrária também já vinham se delineando. A grilagem de terras, por sua vez, vem sendo estimulada por uma série de legislações criadas desde o segundo governo Lula e aprofundadas no governo Temer. A violência contra os movimentos sociais e povos do campo já vinha crescendo em governos anteriores, embora seja verdade que Bolsonaro foi pioneiro em estimular abertamente tais práticas e buscar mecanismos de sua legitimação.

Portanto, o governo Bolsonaro está dando passos largos para assegurar mecanismos que viabilizem a expansão do agronegócio sobre terras públicas, embora nem todos esses mecanismos tenham sido postos em marcha neste governo, alguns já haviam sido implantados anteriormente, como a titulação privada das terras dos assentamentos, iniciada sob FHC, praticamente suspensa pelos governos petistas, recolocada em marcha acelerada pelo governo Temer e intensificadas ainda mais no atual governo. Já a abertura das terras indígenas para o agronegócio (e outros negócios) é uma antiga ambição dos ruralistas que o atual governo encampou de forma inédita.

Assim, podemos afirmar que, mais do que ruptura, as políticas do governo Bolsonaro para o campo representam um aprofundamento da lógica violenta e predatória que marca o desenvolvimento do campo brasileiro sob a hegemonia do agronegócio. A diferença é que isto se faz agora de forma escancarada, sem qualquer verniz e sem qualquer concessão aos movimentos sociais e povos do campo, ao contrário do que aconteceu em governos anteriores, nos quais, em diferentes graus, havia diálogo e políticas que, sem afetar a hegemonia do agronegócio, atendiam a algumas das reivindicações destes segmentos, agora considerados inimigos a serem eliminados.

Os governos petistas, ao abandonarem a reforma agrária e colocarem em marcha a contrarreforma agrária, ignoraram que, desde os primórdios da colonização, terra é sinônimo de poder econômico e político no Brasil. Ao fortalecerem economicamente o agronegócio, os sucessivos governos também fortaleceram politicamente os setores mais retrógrados da sociedade brasileira. E estes, fortalecidos, se voltaram não só contra os governos petistas, vide o golpe 
contra Dilma, mas contra os movimentos e povos do campo. O ovo estava sendo chocado, agora o monstro está à solta, espalhando terror no campo.

Contudo, se virarmos a seta à esquerda para construir um outro modelo de agricultura, cabe-nos a aposta e engajamento nas lutas campesinas, pois esse processo não ocorreu pacificamente, mas eivado de resistência por parte dos trabalhadores rurais, que se lançaram num processo de luta pela terra. Contrariamente ao desenvolvimento desse projeto, que se expande combinando avanços econômicos corporativos com falta de democracia, danos socioambientais e violação de direitos, os movimentos sociais resistem e lutam pelo direito à moradia, à terra, ao trabalho em atividades tradicionais e camponesas, como pescadores, caiçaras, indígenas, quilombolas, e posseiros, pequenos agricultores familiares, bem como, lutam por direitos trabalhistas e sociais e por uma sociabilidade para além dos direitos.

Buscando construir alternativas às consequências geradas por este modelo, as diversas organizações camponesas e de trabalhadores rurais, articulados à Via Campesina, ${ }^{27}$ realizam lutas por um novo modelo agrícola que prime pela preservação dos recursos naturais, pela agroecologia, pela produção de alimentos saudáveis para a população, pela viabilização da permanência do pequeno produtor no campo, entre outros elementos, para construção de uma nova sociedade.

Nesse ínterim, o trabalhador camponês vem criando e recriando seu espaço de produção resistindo às formas repressoras e dominantes de controle dos territórios que violam o direito à terra das comunidades camponesas, mesmo no movimento conflitivo e contraditório do capital nas diversas regiões do país. Numa realidade em que a sociedade burguesa expropria não só as condições materiais para reprodução da vida, mas também as condições imateriais que se relacionam com os meios sociais de se produzir conhecimento, são urgentes e necessários projetos mais audaciosos que fortaleçam a identidade de classe para transformações que apontem para tempos melhores. É fundamental que a classe trabalhadora retome radicalmente sua autonomia, seu protagonismo, sua identidade e reformule sua agenda de lutas e estratégias políticas para consolidar um novo projeto societário em tempos de barbárie.

27 Organização internacional que articula movimentos sociais do campo criada em 1993, que aglutina camponeses, trabalhadores sem-terra, povos indígenas, de todo o mundo. Defende a agricultura verdadeiramente sustentável cosmo forma de prover a justiça social e dignidade. Declara-se contrária ao agronegócio e às multinacionais. É um movimento autônomo, pluralista e multicultural. Sua principal defesa é a soberania alimentar e a luta pelo impedimento do processo destrutivo neoliberal. Mais informações disponíveis no sítio: www.viacampesina.org. 
Esta conjuntura analisada dificulta e, até mesmo, tende a inviabilizar as possibilidades de realização de uma reforma agrária progressista, que seja sinônimo de justiça social, desenvolvimento econômico e conservação ambiental. Assim, a resistência camponesa indígena e quilombola na luta por terra e território se faz legítima e necessária para impedir o avanço desenfreado e ganancioso do agronegócio. A reforma agrária só terá êxito se levar em consideração a implementação de um projeto que viabilize a vida dos povos do campo, garantindo o atendimento das necessidades de reprodução material e social destes, utilizando-se das suas experiências de vida e assim transformando a luta pela terra numa luta por uma nova sociabilidade.

\section{Referências}

AGÊNCIA ESTADO. "Invadiu? É chumbo", afirma Bolsonaro em palestra no Rio de Janeiro. O Tempo, Belo Horizonte, 22 maio 2018, Eleições 2018. Disponível em: <https://www.otempo.com.br/politica/invadiu-e-chumbo-afirma-bolsonaro-em-palestra-no-rio-de-janeiro-1.1789465> . Acesso em: 22 maio 2020 .

ALENTEJANO, P. A política agrária do governo Temer: a pá de cal na agonizante reforma agrária brasileira? OKARA, João Pessoa, v. 12, n. 2, p. 308-325, ago. 2018.

BARBOZA, D. R. A construção da democracia (vulgar) no processo da revolução burguesa no Brasil. 2014. 566 f. Tese (Doutorado em Serviço Social) - Programa de Pós-Graduação em Serviço Social, Faculdade de Serviço Social, Universidade do Estado do Rio de Janeiro, Rio de Janeiro, 2014.

BARBOZA, D. R.; BOTELHO, J.; LUSTOSA, M. G. O. P.; SANT'ANA, R. S. A Questão Agrária na Formação Social Brasileira: desafios contemporâneos à Reforma Agrária. In: BARBOZA, D. R.; PEREIRA, L. D.; PEREIRA, T. D.; RAMOS, A. (Org.). Desenvolvimento, formação social brasileira e políticas públicas: subsídios analíticos para o Serviço Social. 1. ed. Uberlândia: Navegando Publicações, 2019. p. 61-80.

BARTRA, A. Con los pies sobre la tierra: despojo y resistencia en los territorios. Ciudad de México: Ed. Itaca, 2015.

BRASIL. Lei Complementar 87/1996 (Lei Kandir), de 13 de setembro de 1996. Dispõe sobre o imposto dos Estados e do Distrito Federal sobre operações re- 
lativas à circulação de mercadorias e sobre prestações de serviços de transporte interestadual e intermunicipal e de comunicação, e dá outras providências. Diário Oficial [da] República Federativa do Brasil, Poder Executivo, Brasília, DF, 13 set. 1996. p. 18261. Disponível em: <http://www.planalto.gov.br/ ccivil_03/leis/lcp/lcp87.htm>. Acesso em: 15 de set. 2020

Medida Provisória No 422/2008, de 25 de Março de 2008. Dá nova redação ao inciso II do par. $2^{\circ}$-b do art. 17 da lei no 8.666, de 21 de junho de 1993, que regulamenta o art. 37, inciso XXI, da Constituição, e institui normas para licitações e contratos da administração pública. Diário Oficial [da] República Federativa do Brasil, Poder Executivo, Brasília, DF, 26 mar. 2008, p. 4. Disponível em: https://legislacao.presidencia.gov.br/atos/? tipo $=M P V \&$ numero $=422 \& a n o=2008 \& a t o=328 \mathrm{c} 3 \mathrm{YU} 10 \mathrm{dVpWT} 8 \mathrm{e} 2$. Acesso em: 13 set. 2020

. Medida Provisória No 458/2009, De 10 De Fevereiro De 2009.

Dispõe sobre a regularização fundiária das ocupações incidentes em terras situadas em áreas da união, no âmbito da amazônia legal, altera as leis nº ${ }^{\circ} 8.666$, de 21 de junho de 1993, 6.015, de 31 de dezembro de 1973, 6.383, de 7 de dezembro de 1976, e 6.925, de 29 de junho de 1981, e dá outras providências. Diário Oficial [da] República Federativa do Brasil, Poder Executivo, Brasília, DF, 11 fev. 2009, p. 1. Disponível em: < https://legislacao.presidencia.gov.br/atos/? tipo $=$ MPV\&numero $=458 \&$ ano $=2009 \&$ ato $=35$ eQTUE9EeVpWTdd2 $>$. Aces so em: 18 set. 2020

Lei ${ }^{\circ}$ 13.465/2017, de 11 de Julho de 2017. Dispõe sobre a regularização fundiária rural e urbana, sobre a liquidação de créditos concedidos aos assentados da reforma agrária e sobre a regularização fundiária no âmbito da Amazônia Legal; institui mecanismos para aprimorar a eficiência dos procedimentos de alienação de imóveis da União; altera as Leis $n{ }^{\text {os }} 8.629$, de 25 de fevereiro de 1993, 13.001, de 20 de junho de 2014 , 11.952, de 25 de junho de 2009, 13.340, de 28 de setembro de 2016, 8.666, de 21 de junho de 1993, 6.015, de 31 de dezembro de 1973, 12.512, de 14 de outubro de 2011 , 10.406, de 10 de janeiro de 2002 (Código Civil), 13.105, de 16 de março de 2015 (Código de Processo Civil), 11.977, de 7 de julho de 2009, 9.514, de 20 de novembro de 1997, 11.124, de 16 de junho de 2005, 6.766, de 19 de dezembro de 1979, 10.257, de 10 de julho de 2001, 12.651, de 25 de maio de 2012, 13.240, de 30 de dezembro de 2015, 9.636, de 15 de maio de 1998, 8.036, de 11 de maio de 1990, 13.139, de 26 de junho de 2015, 11.483, de 31 de maio de 2007, e a 
12.712, de 30 de agosto de 2012, a Medida Provisória no 2.220, de 4 de setembro de 2001, e os Decretos-Leis n ${ }^{\circ}$ 2.398, de 21 de dezembro de 1987, 1.876, de 15 de julho de 1981, 9.760, de 5 de setembro de 1946, e 3.365, de 21 de junho de 1941; revoga dispositivos da Lei Complementar $n^{\circ}$ 76, de 6 de julho de 1993, e da Lei no 13.347, de 10 de outubro de 2016; e dá outras providências.

Diário Oficial [da] República Federativa do Brasil, Poder Executivo, Brasília, DF, 12 jul 2017, p. 1. Disponível em: < http://www.planalto.gov.br/ ccivil_03/_ato2015-2018/2017/lei/113465.htm>. Acesso em: 18 set. 2020.

. Medida provisória n. 910/2019, de 10 de dezembro de 2019. Altera a Lei $n^{\circ} 11.952$, de 25 de junho de 2009, que dispõe sobre a regularização fundiária das ocupações incidentes em terras situadas em áreas da União, a Lei n ${ }^{\circ}$ 8.666, de 21 de junho de 1993, que institui normas para licitações e contratos da administração pública, e a Lei no 6.015, de 31 de dezembro de 1973, que dispõe sobre os registros públicos. Diário Oficial [da] República Federativa do Brasil, Poder Executivo, Brasília, DF, 10 dez. 2019a, p. 4-6. Disponível em: $<$ http://www.planalto.gov.br/ccivil_03/_ato2019-2022/2019/Mpv/ mpv910.htm >. Acessso em: 18 set. 2020.

. Lei n. 13.870/2019, DE 17 DE SETEMBRO DE 2019. Altera a Lei $\mathrm{n}^{\circ} 10.826$, de 22 de dezembro de 2003, para determinar que, em área rural, para fins de posse de arma de fogo, considera-se residência ou domicílio toda a extensão do respectivo imóvel. . Diário Oficial [da] República Federativa do Brasil, Poder Executivo, Brasília, DF, 18 set. 2019b, p. 2. Disponível em: <https://www.in.gov.br/web/dou/-/lei-n-13870-de-17-de-setembro-de2019-216803986>. Acesso em: 20 set. 2020.

. Constituição Federal (1891). Brasília: Planalto, 2020a. Disponível em: <http://www.planalto.gov.br/ccivil_03/Constituicao/ Constituicao91.htm>. Acesso em: 20 set. 2020.

. Constituição Federal (1934). Brasília: Planalto, 2020b. Disponível em: <http://www.planalto.gov.br/ccivil_03/constituicao/constituicao34.htm>. Acesso em: 20 set. 2020.

. Projeto de Lei 191/2020, de 05 de fevereiro de 2020. Regulamenta o \$ $1^{\circ}$ do art. 176 e o $\$ 3^{\circ}$ do art. 231 da Constituição para estabelecer as condições específicas para a realização da pesquisa e da lavra de recursos minerais e hidrocarbonetos e para o aproveitamento de recursos hídricos para geração de energia elétrica em terras indígenas e institui a indenização pela restrição do usufruto de terras indígenas. Diário Oficial [da] República Federativa do Brasil, 
Poder Executivo, Brasília, DF, p. 1. 05 fev. 2020c. Disponível em: https://www.camara.leg.br/proposicoesWeb/fichadetramitacao?idProposicao $=2236765$. Acesso em: 13 set. 2020

Projeto de Lei n. 2.633/2020, de 14 de maio de 2020. Altera a Lei ${ }^{\circ}$ 11.952, de 25 de junho de 2009, que dispõe sobre a regularização fundiária das ocupações incidentes em terras situadas em áreas da União; a Lei n ${ }^{\circ}$ 8.666, de 21 de junho de 1993, que institui normas para licitações e contratos da administração pública; a Lei no 6.015, de 31 de dezembro de 1973, que dispõe sobre os registros públicos; a fim de ampliar o alcance da regularização fundiária e dar outras providências. Diário Oficial [da] República Federativa do Brasil, Poder Executivo, Brasília, DF, 14 mai. 2020d, p. 1. Disponível em: < https:// www.camara.leg.br/propostas-legislativas/2252589>. Acesso em: 18 set. 2020. CANDIDO, A. Prefácio. In: CRUZ COSTA, J. Pequena história da República. 3. ed. Rio de Janeiro: Editora Civilização Brasileira, 1989.

CARNEIRO, F. F.; AUGUSTO, L. G da S.; RIGOTTO, R. M.; FRIEDRICH, K.; BÚRIGO, A. C. (orgs.). Dossiê ABRASCO: um alerta sobre os impactos dos agrotóxicos na saúde. Rio de Janeiro: ESPJV; São Paulo: Expressão Popular, 2015.

COGGIOLA, O. La Cuestión Agraria en Brasil. Grupo de Pesquisa História e Economia Mundial Contemporâneas. Artigos. p. 1-35. Março de 2007. Disponível em: <http://www.rebelion.org/docs/39143.pdf>. Acesso em: 30 jul. 2020.

COSTA, E. V. da. Da monarquia à república: momentos decisivos. 9. ed. São Paulo: Editora UNESP, 2010.

CPT. COMISSÃO PASTORAL DA TERRA. Conflitos no campo: Brasil 2019/Centro de documentação Dom Tomás Balduino. Goiania: CPT NACIONAL, 2020.

DELGADO, G. C. A questão agrária no Brasil, 1950-2003. In: JACCOUD, L. Questão social e políticas sociais no Brasil contemporâneo. Brasília: IPEA, 2005. p. 51-90.

. O que significa agronegócio no Brasil. Brasília: IPEA, 2006

Do capital financeiro na agricultura à economia do agronegócio: mudanças cíclicas em meio século (1965-2012). Porto Alegre: Editora da UFRGS, 2012.

FAUSTO, B. História do Brasil. 14. ed. São Paulo: Edusp, 2012. 
FERNANDES, F. A revolução burguesa no Brasil. 2. ed. Rio de Janeiro: Zahar Editores, 1976.

Capitalismo dependente e classes sociais na América Latina. 3. ed. Rio de Janeiro: Ed. Zahar Editores, 1981.

FERNANDES, B. M. Agronegócio e Reforma Agrária. In: XVII Encontro Nacional de Geografia Agrária, 2004, Gramado - RS. Anais do XVII Encontro Nacional de Geografia Agrária: Tradição x Tecnologia: as novas territorialidades do espaço agrário brasileiro. Porto Alegre: UFRGS, 2004. S/p.

(Org.) Campesinato e agronegócio na América Latina. São Paulo: Expressão Popular, 2008.

. (et. al.). A questão agrária no primeiro ano do governo Bolsonaro. São Paulo: DATALUTA/NERA, 2020.

GONZALES, J. Brasil quer legalizar o arrendamento agrícola de terras indígenas. Mongabay (on line). 08 mar. 2019. Mongabay Series: Agronegócio na Amazônia. Traduzido por Debora dos Santos Gonzales. Disponível em: $<$ https://brasil.mongabay.com/2019/03/brasil-quer-legalizar-o-arrendamento-agricola-de-terras-indigenas >. Acesso em: 16 ago. 2020.

HARVEY, D. O Novo Imperialismo. 7. ed. São Paulo: Edições Loyola, 2004. HEREDIA, B.; LEITE, S. P.; PALMERA, M. Sociedade e Economia do "Agronegócio" no Brasil. Revista Brasileira de Ciências Sociais, São Paulo, v. 25, n. 74, p.159-196, out. 2010.

IAMAMOTO, M. V. Trabalho e indivíduo social: um estudo sobre a condição operária na agroindústria canavieira paulista. 2. ed. São Paulo: Cortez, 2006.

. Serviço Social em tempo de capital fetiche: capital financeiro, trabalho e questão social. São Paulo: Cortez, 2007.

IANNI, O. O Ciclo da Revolução Burguesa. Petrópolis: Vozes, 1985.

IBGE. Censo agropecuário 2017, Rio de Janeiro, v. 8, p. 1-105, 2019. Disponível em: < https://biblioteca.ibge.gov.br/visualizacao/periodicos/3096/ agro_2017_resultados_definitivos.pdf > . Acesso em: 13 set. 2020.

. Produção Agrícola Municipal - PAM. Brasília: IBGE, 2020a. Disponível em: <https://www.ibge.gov.br/>. Acesso em: 13 set. 2020.

. Pesquisa Pecuária Municipal - PPM. Brasília: IBGE, 2020b. Disponível em: <https://www.ibge.gov.br/>. Acesso em: 13 set. 2020. 
INCRA. Sistema Nacional De Cadastro Rural - SNCR. Disponível em: $<$ http://www.incra.gov.br/sites/default/files/uploads/estruturafundiaria/estat-sticas-de-im-veisrurais-/brasil_cadastro_imoveis_rurais_geral_pub_e_priv.pdf $>$. Acesso em: 13 set. 2020a.

Relatórios de Gestão. Disponível em: < http://antigo.incra.gov.br/ pt/relatorios-gestao >. Acesso em: 13 set. 2020.

LEHER, R. Iniciativa para a integração da Infraestrutura regional da América Latina, Plano de Aceleração do Crescimento e Questão Ambiental: desafios epistêmicos. Caderno de Estudo dos cursos de emancipações e realidade brasileira, Rio de Janeiro: Outro Brasil/Laboratório de Políticas Públicas UERJ, p. 65-81, mar. 2009.

MARQUES, M. I. M. A atualidade do uso do conceito camponês. Revista Nera, Presidente Prudente, ano 11, n. 12, p. 57-67, jan./jun. 2008.

MARTINS, J. de S. Reforma agrária - o impossível diálogo sobre a História possível. Tempo Social, São Paulo, v. 11, n. 2, p. 97-128, out. 1999.

A sociedade vista do abismo: novos estudos sobre exclusão, pobreza e classes sociais. Petrópolis, RJ: Vozes, 2002.

Reforma agrária no Brasil: história e atualidade da luta pela terra no Brasil. São Paulo: Fundação Perseu Abramo, 2003.

MÜLLER, G. Complexo agroindustrial e modernização agrária. São Paulo: HUCITEC, 1989.

OLIVEIRA, A. U. de. A questão da aquisição de terras por estrangeiros no Brasil - um retorno aos dossiês. Agrária (On Line), São Paulo, n. 12, p. 3-113, jun. 2010.

PALMEIRA, M. Modernização, Estado e questão agrária. Estudos Avançados, São Paulo, v. 3, n. 7, p. 87-108, set./dez. 1989. Disponível em: <http:// www.scielo.br/pdf/ea/v3n7/v3n7a06.pdf>. Acesso em: 02 ago. 2020.

PARAGUASSU, L. Bolsonaro diz que não irá demarcar mais pedidos de terras quilombolas. Terra On line. 10 mar. 2020. Brasil. Disponível em: <https:// www.terra.com.br/noticias/brasil/bolsonaro-diz-que-nao-ira-demarcarmais-pedidos-de-terras-quilombolas,c84b0e29893073548b2d922fc2c843b43hikpw6z.html>. Acesso em: 16 ago. 2020.

PRADO JR., C. Formação do Brasil Contemporâneo: colônia. São Paulo: Brasiliense; Publifolha, 2000. 
. História econômica do Brasil. São Paulo: Brasiliense, 2008.

. Evolução política do Brasil: e outros ensaios. São Paulo: Companhia das Letras, 2012.

PRIZIBISCZKI, C. Mineração em terras indígenas: a proposta do governo Bolsonaro em 10 perguntas e respostas. O Eco (on line). 09 fev. 2020. Disponível em: < https://www.oeco.org.br/reportagens/mineracao-em-terras-indigenas-a-proposta-do-governo-bolsonaro-em-10-perguntas-e-respostas $>$. Acesso em: 09 fev. 2020.

ROCHA, L. Aumenta a bancada BBB: Bíblia, Boi e Bala. Revista Época On line. 4 fev. 2015. Coluna Felipe Batury. Disponível em: < https:/ / epoca.globo.com/colunas-e-blogs/felipe-patury/noticia/2015/02/kokay-aumenta-bancada-bbb-biblia-boi-e-bala.html> Acesso em: 07 set. 2020.

RODRIGUES, J. H. Conciliação e reforma no Brasil. Um desafio históricocultural. 2. ed. Rio de Janeiro: Nova Fronteira, 1982.

STÉDILE, J. P. (Org.). Introdução. In: . A questão agrária no Brasil: o debate na esquerda - 1960-1980. São Paulo: Expressão Popular, 2005. p.1733.

A Questão agrária no Brasil: o debate na década de 2000. São Paulo: Expressão Popular, 2013.

SVAMPA, M. "Consenso de los commodities" y linguagens de valorização em América Latina. Revista Nueva Sociedad, Buenos Aires, n. 244, p. 30-46, mar./abr. 2013.

VERDÉLIO, A. Bolsonaro diz que não fará demarcação de terras indígenas. Agência Brasil On line. 16 ago. 2019. Política. Disponível em: < https://agenciabrasil.ebc.com.br/politica/noticia/2019-08/bolsonaro-diz-que-nao-farademarcacao-de-terras-indigenas> Acesso em: 16 ago. 2020. 